\title{
Implementasi Cloud Based Video Conference System Menggunakan Amazon Web Service
}

\author{
Alde Alanda ${ }^{a,}$, Deni Satria $^{b}$ \\ ${ }^{a, b}$ Jurusan Teknologi Informasi Politeknik Negeri Padang, Kampus Limau Manis, Kota Padang 25163, Indonesia
}

\section{ARTICLE INFORMATION}

Received: November $11^{\text {th }}, 2021$ February 00,00

Revised: December 30 ${ }^{\text {th }}, 2021$

Available online: December $31^{\text {th }}, 2021$

\section{KEYWORDS}

Video conference, Cloud, Amazon Web Service, AWS EC2

\section{CORRESPONDENCE}

E-mail: alde@pnp.ac.id

\section{A B S T $\mathbf{R}$ A C $\mathbf{T}$}

Since December 2019, the world and Indonesia have fought a major disaster, namely the Covid 19 virus pandemic. With the rapid spread or transmission of the virus, the Indonesian government decided to impose working from home that impacted the education sector. Students and lecturers cannot conduct lectures face-to-face in class or laboratory but complete online. To support online courses, we need an open-source system developed by the campus. This application was developed using cloud technology and Jitsi as an open-source videoconferencing system. This system uses Amazon Web Service (AWS) as cloud infrastructure. The use of cloud technology is to speed up the application production process without building infrastructure on the local network. This study performs features tests in video conferencing applications and resources usage on the server. As a result of testing, the application ran as expected with several important features used for learning, such as chat, share screen, and recording that can run optimally. The result tested the system resources based on the number of participants. The number of participants joining the meeting was from $25-78$ participants simultaneously, with RAM usage $2.1 \mathrm{~GB}-2.8 \mathrm{~GB}$ and CPU usage was from $1.4 \%-38.1 \%$. This result shows the cloud server can handle above 100 participants and run simultaneously for several meetings.

\section{PENDAHULUAN}

Sejak kemunculan pandemi Covid-19 diakhir tahun 2019 banyak aspek kehidupan ikut berubah, seperti cara beraktifitas sehari-hari dan cara bekerja. Selain itu, Covid-19 juga mendorong berbagai pihak, baik itu individu, organisasi maupun industri untuk dapat beradaptasi dengan perubahan ini [1]. Salah satu perubahan yang paling terlihat yaitu work from home (WFH)[1]. Pemerintah Indonesiapun telah mengeluarkan kebijakan tentang pelaksanaan WFH[2].

Kebijakan mengenai WFH ternyata berpengaruh terhadap penggunaan teknologi informasi, salah satunya yaitu pemanfaatan berbagai layanan video conference. Kebutuhan akan video conference saat pandemi merupakan sesuatu yang tidak bisa diabaikan, karena video conference adalah alternatif utama agar komunikasi tetap berjalan, khususnya dalam proses pembelajaran[3]. Video conference mempunyai potensi besar dalam pembelajaran untuk diterapkan di sekolah dan perguruan tinggi untuk memfasilitasi pembelajaran jarak jauh[4]. Tingginya tingkat penggunaan video conference juga dapat dipandang dari sisi pasar. Hasil penelitian Fortune Business Insight menyatakan bahwa terjadi peningkatan pertumbuhan pasar video conference dari USD 6,28 miliar pada tahun 2021 hingga tahun 2028 nanti menjadi USD 12,99 miliar. Hal ini didorong akibat munculnya kebutuhan akan teknologi yang dapat membantu komunikasi jarak jauh, terutama di bidang pendidikan $[5]$.

Teknologi video conference membutuhkan sumber daya yang cukup mahal dan proses implementasinya sangat kompleks.[6]. Hal ini dapat diatasi dengan penggunaan teknologi cloud computing. Teknologi cloud computing merupakan sebuah upaya untuk meminimalkan biaya pengadaan infrastruktur teknologi informasi yang cukup besar[7]. Penggunakan teknologi cloud untuk mempercepat proses produksi aplikasi tanpa harus membangun infrastuktur di jaringan lokal. Cloud computing juga dapat dikatakan sebagai media yang dinamis, jasa layanan berbasis on-demand, mempunyai platform dan media penyimpanan, pengelolaannya menggunakan daya komputasi dan virtualisasi yang handal[8]. Cloud computing merupakan sebuah model client-server, dimana sumber daya seperti server, penyimpanan, jaringan dan perangkat lunank dapat dipandang sebagai layanan yang dapat diakses oleh pengguna secara remote dan setiap saat[9]. Salah satunya yaitu layanan cloud yang banyak digunakan saat ini yaitu Amazon Web Service (AWS).

Untuk mengimplementasikan video conference pada layanan cloud, perlu diketahui kapasitas sumber daya yang digunakan sesuai dengan kebutuhan. Oleh karena itu, pada artikel ini 
dilakukan implementasi aplikasi video conference pada layanan AWS untuk mengetahui besarnya penggunaan awal sumber daya saat video conference berlangsung. Artikel ini diharapkan dapat menjadi acuan perencanaan penentuan sumber daya layanan cloud yang akan digunakan untuk penerapan aplikasi video conference.

\section{METODE}

Sistem video conference dibangun menggunakan dua platform utama, yaitu aplikasi video conference Jitsi Meet, dan layanan cloud computing Amazon Web Service (AWS). Dari pengimplementasian ini kemudian dilakukan pengujian fungsionalitas fitur Jitsi dan penggunaan sumber daya pada server virtual AWS. Pengujian dilakukan terhadap 12 variasi jumlah partisipan yang terlibat selama video conference berlangsung.

Sistem video conference yang diajukan pada artikel ini adalah aplikasi video conferece Jitsi yang dibangun pada server sendiri, dalam artian virtual server yang disewa pada layanan AWS. Sistem juga dapat diakses pada domain name yang telah ditentukan sesuai keinginan, yaitu https://syahrul.tk. Selain itu, sistem memiliki authentication host code untuk menjamin agar room meeting hanya dapat dibuat oleh host atau administrator. Secara keseluruhan, alur kerja sistem ditunjukkan pada Gambar 1.

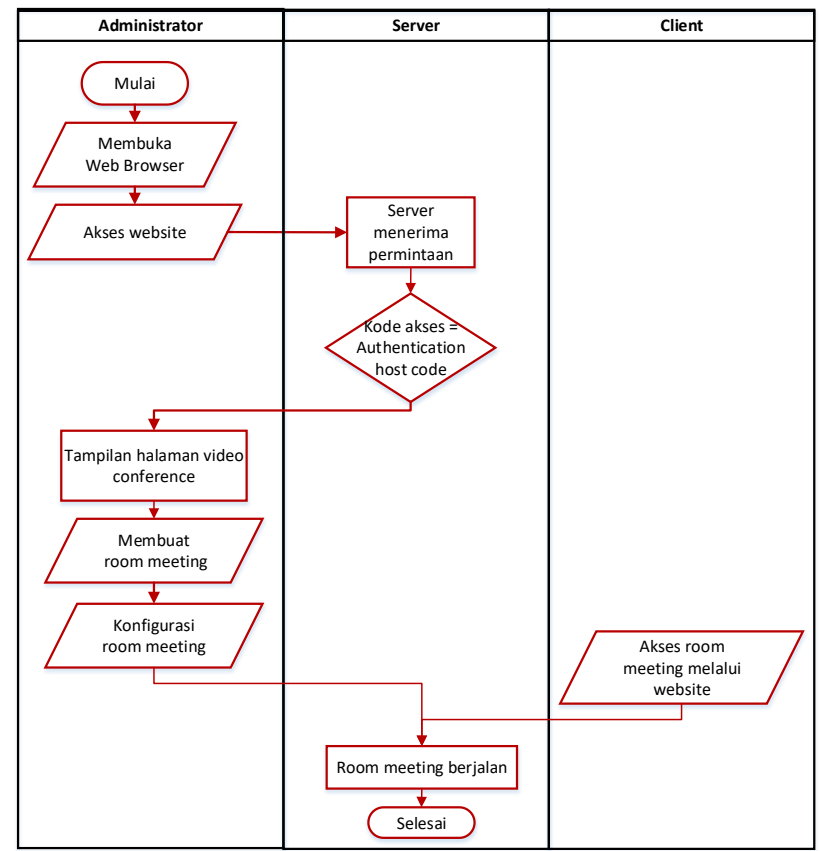

Gambar 1. Alur kerja sistem.

Berdasarkan Gambar 1, sistem terdiri dari 3 komponen utama, yaitu:

a) Administrator, atau dapat disebut juga sebagai admin, adalah partisipan yang memiliki akses penuh pada sistem. Admin memiliki authentication host code. Hal ini untuk menjamin bahwa hanya admin yang dapat melakukan konfigurasi server dan membuat room meeting.

b) Server, merupakan perangkat lunak yang memberikan layanan atas permintaan dari administrator maupun dari client.

76 Alde Alanda c) Client, merupakan pengguna dari sistem ini. Client hanya bisa mengakses video conference yang telah dikonfigurasi dan diberikan akses oleh administrator. Client tidak dapat melakukan konfigurasi atau perubahan lainnya pada sistem.

\section{Amazon Web Service (AWS)}

AWS merupakan salah satu penyedia layanan cloud terbesar di seluruh dunia dengan run rate tertinggi yang hampir mencapai USD 10 miliar. AWS telah mengambil alih 30\% pangsa pasar, menggeser pesaing-pesaingnya[10]. AWS memiliki perlindungan keamanan tingkat tinggi. Penggunaan layanan cloud ini dapat menghindari resiko keamanan dan mengurangi tingkat kebocoran data pengguna. Data yang disimpan di AWS cloud memiliki kemungkinan hilang atau rusak yang jauh lebih kecil[11].

AWS menyediakan berbagai layanan cloud yang dapat dikombinasikan sesuai dengan kebutuhan bisnis atau organisasi. Layanan-layanan tersebut dikelompokkan menjadi: komputasi, jaringan, penyimpanan dan pengiriman konten, database, analitik, layanan aplikasi, penerapan dan manajemen, seluler dan aplikasi[12].

Salah satu layanan AWS adalah Elastic Computing Services (EC2). Amazon EC2 merupakan layanan yang menyediakan kapasitas komputasi yang dapat diubah ukurannya [13]. Layanan ini menawarkan antarmuka yang sederhana sehingga pengguna dapat melakukan konfigurasi dengan mudah. Selain itu, pengguna memiliki kendali penuh atas berbagai sumber daya komputasi. Amazon EC2 menawarkan kemudahan dalam melakukan perubahan atas skala kapasitas sumber daya yang digunakan. Sehingga, jika kebutuhan kapasitas suatu sumber daya perlu diubah, dinaikkan ataupun diturunkan, maka pengguna dapat melakukan perubahan dengan cepat[13]. EC2 mengurangi biaya dengan membebankan biaya kepada pengguna berdasarkan kapasitas sumber daya yang digunakan saja [10].

Pengguna AWS dapat menyewa layanan mesin virtual Amazon yang disebut sebagai instance. Amazon EC2 memiliki berbagai jenis instance yang dapat disesuaikan dengan kebutuhan pengguna. Jenis-jenis instance ini terdiri dari berbagai kombinasi $\mathrm{CPU}$, memori, penyimpanan, dan kapasitas jaringan. Setiap jenis instance menyertakan satu atau beberapa ukuran instance. Salah satu kelompok instance yaitu General Purpose Instance yang bertujuan umum untuk memberikan keseimbangan sumber daya komputasi, memori, dan jaringan, dan dapat digunakan untuk berbagai beban kerja yang beragam. Instance ini ideal untuk aplikasi yang menggunakan sumber daya ini dalam proporsi yang sama seperti server web dan repositori kode. General Purpose Instance memiliki 14 tipe, salah satunya yaitu t2. Tipe instance ini menawarkan performa kinerja CPU yang baik [14].

Pada artikel ini, digunakan Amazon EC2 sebagai instance web server dengan tipe t2.xlarge. Tipe instance ini memiliki $4 \mathrm{vCPU}$ (virtual Central Processing Unit) dan 16 GB RAM (Random Access Memory). Kedua sumber daya akan diuji penggunaannya saat video conference berlangsung. Sehingga dapat diketahui kapasitas atau persentase sumber daya yang terpakai saat video conference dengan 12 variasi jumlah partisipan. Keseluruhan 
spesifikasi layanan AWS yang digunakan pada artikel ini ditunjukkan pada Tabel 1.

Tabel 1. Spesifikasi layanan AWS yang digunakan.

\begin{tabular}{|c|c|}
\hline $\begin{array}{l}\text { Sistem } \\
\text { Operasi }\end{array}$ & : Ubuntu Server 18.04 \\
\hline Instance type & $\begin{array}{l}\text { : t2.xlarge dengan } 4 \text { vCPUs dan } 16 \text { GB } \\
\text { RAM. }\end{array}$ \\
\hline Storage & $: 30$ GB SSD \\
\hline \multirow[t]{6}{*}{$\begin{array}{l}\text { Security } \\
\text { group }\end{array}$} & $\begin{array}{l}\text { : launch- wizard-2 dengan inbound rules } \\
\text { sebagai berikut: }\end{array}$ \\
\hline & 1) HTTP (Hypertext Transfer \\
\hline & Protocol) port 80 \\
\hline & 2) $\mathrm{SSH}$ (Secure Shell) port 22 \\
\hline & $\begin{array}{l}\text { 3) UDP (User Data Protocol) port } \\
\text { range } 10000-20000\end{array}$ \\
\hline & 4) HTTPS (Hypertext Transfer \\
\hline
\end{tabular}

\section{Jitsi Meet}

Jitsi meet merupakan salah satu aplikasi video conference open source. Jitsi meet merupakan gabungan dari beberapa sub projek, yaitu Videobridge (JVB), Jitsi Conference Focus (jicofo), Jitsi Gateway to SIP (jigasi), Jitsi Broadcasting Infrastructure (jibri), dan Prosody seperti yang ditampilkan pada Gambar 2[15].

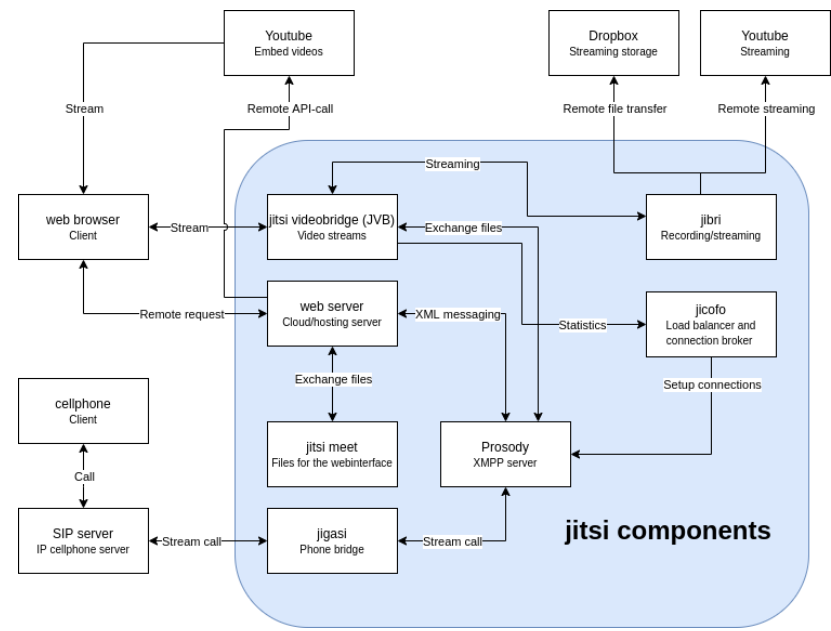

Gambar 2. Infrastruktur Jitsi Meet[15].

Biasanya, Jitsi meet dapat diakses melalui web browser yaitu melalui https://meet.jit.si/[16]. Pada artikel ini, Jitsi diimplementasikan pada server sendiri dengan memanfaatkan AWS sebagai web server. Sehingga, Jitsi Meet tidak lagi diakses menggunakan domain Jitsi melainkan melalui domain yang sudah dikonfigurasikan sebelumnya, yaitu https://syahrul.tk. Dengan demikian, jika suatu instancei atau organisasi mengimplementasikan sistem ini, maka mereka dapat menyesuaikan domain name sesuai dengan yang diinginkan.

Selain fitur dasar video conference, yaitu webcam dan microphone, Jitsi juga dilengkapi dengan berbagi fitur lainnya[16]. Pada artikel ini digunakan 15 fitur Jitsi Meet, ditunjukkan pada Tabel 2. Pada seluruh fitur ini dilakukan pengujian fungsionalitas untuk mengetahui apakah fitur dapat berjalan dengan baik setelah Jitsi diimplementasikan pada AWS.
Pengujian dilakukan dengan mengakses setiap fitur saat video conference berlangsung dan memberikan penilaian berupa keterangan "berhasil" jika fitur dapat digunakan, atau "tidak berhasil" jika fitur tidak dapat digunakan.

Tabel 1. Fitur Jitsi yang digunakan.

\begin{tabular}{clll}
\hline No & \multicolumn{1}{c}{ Fitur } & No & \multicolumn{1}{c}{ Fitur } \\
\hline 1 & Security Options & 9 & Start Live Stream \\
2 & Invitation & 10 & Start Recording \\
3 & Share Screen & 11 & Share a Youtube \\
4 & Raise/Lower Hand & 12 & Blur Background \\
5 & Fitur Chat & 13 & Mute Everyone \\
6 & Toogle Tile View & 14 & Speaker Stats \\
7 & Manage Video Quality & 15 & View Shortcuts \\
8 & View Full Screen & & \\
\hline
\end{tabular}

\section{HASIL DAN PEMBAHASAN}

Hasil implementasi Jitsi Meet pada AWS ditunjukkan pada Gambar 3 dan Gambar 4. Gambar 3 merupakan tampilan awal saat video conference dimulai. Gambar 4 merupakan tampilan fitur Video Quality untuk mengatur kualitas video. fungsi dari fitur ini adalah mengatur kualitas video saat video conference berlangsung. Penggunaan fitur ini berfungsi terkait koneksi masing-masing partisipan. Untuk partisipan yang mempunyai koneksi terbatas bisa memilih kualitas video yang lebih rendah. Pada fitur ini ada 4 pilihan yang disediakan yaitu hanya suara, "low definition", "standard definition" dan "high definition".

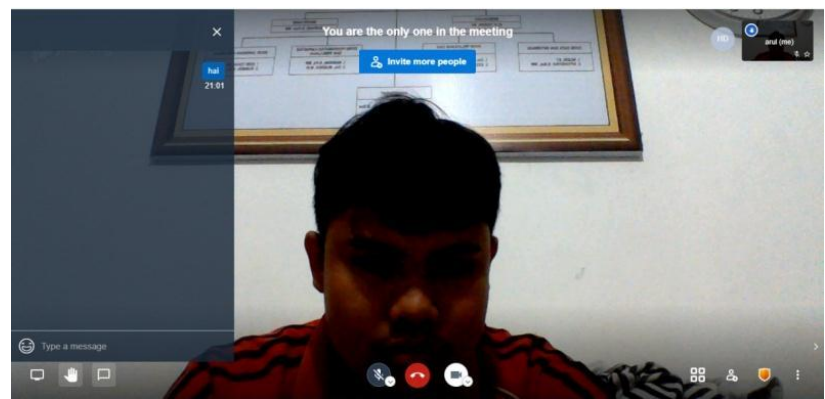

Gambar 3. Tampilan implementasi Jitsi Meet

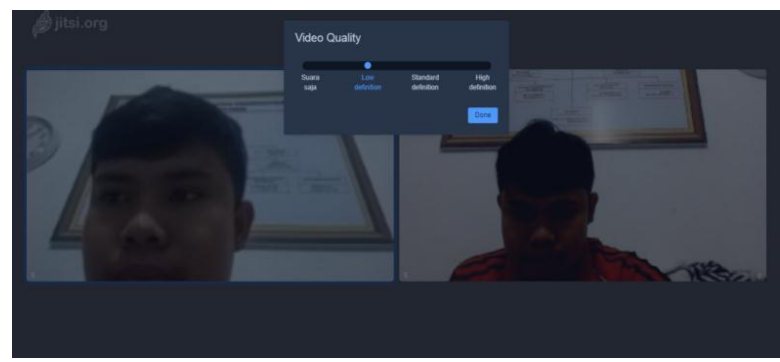

Gambar 4 Pengujian Fitur Video Quality.

\section{Fungsionalitas Fitur Aplikasi Video Conference}

Hasil pengujian fungsionalitas 15 fitur Jitsi ditunjukkan pada Tabel 3. Berdasarkan data ini dapat dilihat bahwa seluruh fitur dapat berjalan dengan baik. 
Tabel 2. Hasil pengujian fungsionalitas fitur.

\begin{tabular}{|c|c|c|c|c|c|}
\hline \multirow{2}{*}{ No } & \multirow{2}{*}{ Fitur } & \multicolumn{3}{|c|}{ Pengujiam ke- } & \multirow{2}{*}{$\begin{array}{c}\text { Persentase } \\
\text { keberhasilan }\end{array}$} \\
\hline & & I & II & III & \\
\hline 1 & Security Options & berhasil & berhasil & berhasil & $100 \%$ \\
\hline 2 & Invitation & berhasil & berhasil & berhasil & $100 \%$ \\
\hline 3 & Share Screen & berhasil & berhasil & berhasil & $100 \%$ \\
\hline 4 & $\begin{array}{l}\text { Raise/Lower } \\
\text { Hand }\end{array}$ & berhasil & berhasil & berhasil & $100 \%$ \\
\hline 5 & Fitur Chat & berhasil & berhasil & berhasil & $100 \%$ \\
\hline 6 & Toogle Tile View & berhasil & berhasil & berhasil & $100 \%$ \\
\hline 7 & $\begin{array}{l}\text { Manage } \\
\text { Quality }\end{array}$ & berhasil & berhasil & berhasil & $100 \%$ \\
\hline 8 & View Full Screen & berhasil & berhasil & berhasil & $100 \%$ \\
\hline 9 & Start Live Stream & berhasil & berhasil & berhasil & $100 \%$ \\
\hline 10 & Start Recording & berhasil & berhasil & berhasil & $100 \%$ \\
\hline 11 & Share a Youtube & berhasil & berhasil & berhasil & $100 \%$ \\
\hline 12 & Blur Background & berhasil & berhasil & berhasil & $100 \%$ \\
\hline 13 & Mute Everyone & berhasil & berhasil & berhasil & $100 \%$ \\
\hline 14 & Speaker Stats & berhasil & berhasil & berhasil & $100 \%$ \\
\hline 15 & View Shortcuts & berhasil & berhasil & berhasil & $100 \%$ \\
\hline
\end{tabular}

\section{Penggunaan RAM dan CPU}

Untuk mengetahui kapasitas sumber daya yang digunakan selama video conference, dilakukan pengujian pada 12 variasi jumlah peserta atau partisipan. Pengujian ini dilakukan saat proses perkuliahan berlangsung pada mata kuliah Keamanan Jarinagn di Jurusan Teknologi Informasi Politeknik Negeri Padang. Pengujian dilakukan dengan memonitoring penggunaan RAM dan CPU pada server.

Gambar 5 merupakan tampilan PutTy untuk memonitoring penggunaan sumber daya pada saat video conference berlangsung dengan jumlah 78 peserta. Penggunaan sumber daya yang dimonitoring ditandai pada kotak merah. Angka 1, 2, 3 dan 4 menampilkan persentase penggunaan CPU core-1, core-2, core-3 dan core-4. "Mem" menampilkan nilai penggunaan RAM.

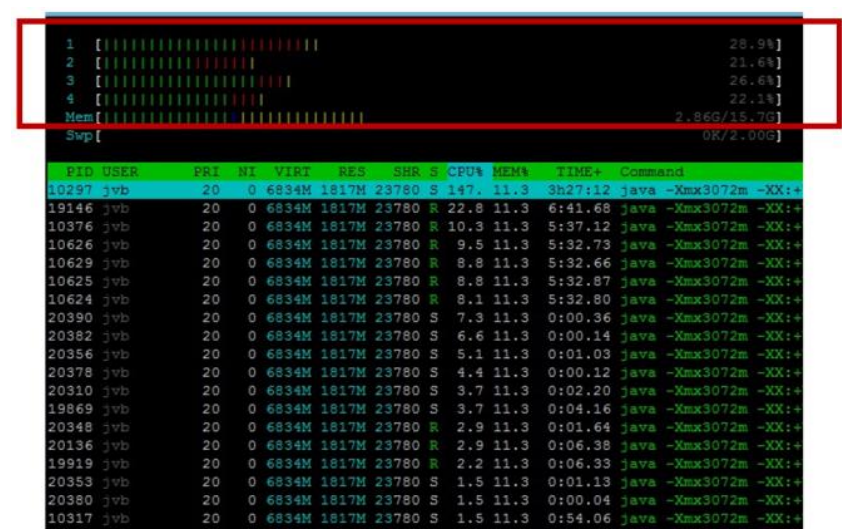

Gambar 5 Monitoring sumber daya pada saat video conference dengan78 peserta

Hasil pengujian untuk keseluruhan variasi partisipan ditunjukkan pada Tabel 4. Data pada Tabel 4 diiilustrasikan pada grafik Gambar 6 dan Gambar 7.
Tabel 3. Hasil pengujian pada seluruh variasi parisipan

\begin{tabular}{lcccccc}
\hline No & Jumlah Partisipan & RAM & Core-1 & Core-2 & Core-3 & Core-4 \\
\hline 1 & 25 Partisipan & $2,71 \mathrm{~GB}$ & $3,7 \%$ & $2,2 \%$ & $1,4 \%$ & $5,0 \%$ \\
2 & 31 Partisipan & $2,72 \mathrm{~GB}$ & $23,0 \%$ & $11,8 \%$ & $13,8 \%$ & $13,7 \%$ \\
3 & 35 Partisipan & $2,74 \mathrm{~GB}$ & $14,5 \%$ & $10,6 \%$ & $15,2 \%$ & $13,1 \%$ \\
4 & 40 Partisipan & $2,75 \mathrm{~GB}$ & $14,3 \%$ & $10,9 \%$ & $12,1 \%$ & $12,1 \%$ \\
5 & 45 Partisipan & $2,77 \mathrm{~GB}$ & $14,6 \%$ & $16,9 \%$ & $12,4 \%$ & $13,9 \%$ \\
6 & 50 Partisipan & $2,80 \mathrm{~GB}$ & $30,2 \%$ & $29,1 \%$ & $30,3 \%$ & $28,5 \%$ \\
7 & 55 Partisipan & $2,82 \mathrm{~GB}$ & $21,3 \%$ & $19,4 \%$ & $22,7 \%$ & $20,8 \%$ \\
8 & 59 Partisipan & $2,83 \mathrm{~GB}$ & $30,4 \%$ & $27,0 \%$ & $27,3 \%$ & $25 \%$ \\
9 & 65 Partisipan & $2,84 \mathrm{~GB}$ & $31,6 \%$ & $22,6 \%$ & $23,3 \%$ & $24,4 \%$ \\
10 & 70 Partisipan & $2,84 \mathrm{~GB}$ & $29,6 \%$ & $25,4 \%$ & $25,2 \%$ & $24,6 \%$ \\
11 & 74 Partisipan & $2,84 \mathrm{~GB}$ & $38,1 \%$ & $29,8 \%$ & $30,3 \%$ & $33,8 \%$ \\
12 & 78 Partisipan & $2,86 \mathrm{~GB}$ & $28,9 \%$ & $21,6 \%$ & $26,6 \%$ & $22,1 \%$ \\
\hline
\end{tabular}

Berdasarkan Gambar 5, dapat dilihat bahwa penggunaan RAM terendah yaitu sebesar $16,94 \%$ dan tertinggi sebesar $17,88 \%$. Dari nilai ini dapat dilihat bahwa penggunaan RAM meningkat seiring kenaikan jumlah partisipan. Kemudian, rata-rata penggunaan RAM saat video conference berlangsung untuk 25 hingga 78 partisipan yaitu sebesar 2,79 GB atau $17 \%$ dari kapasitas RAM. ahwa penggunaan RAM meningkat seiring kenaikan jumlah partisipan.

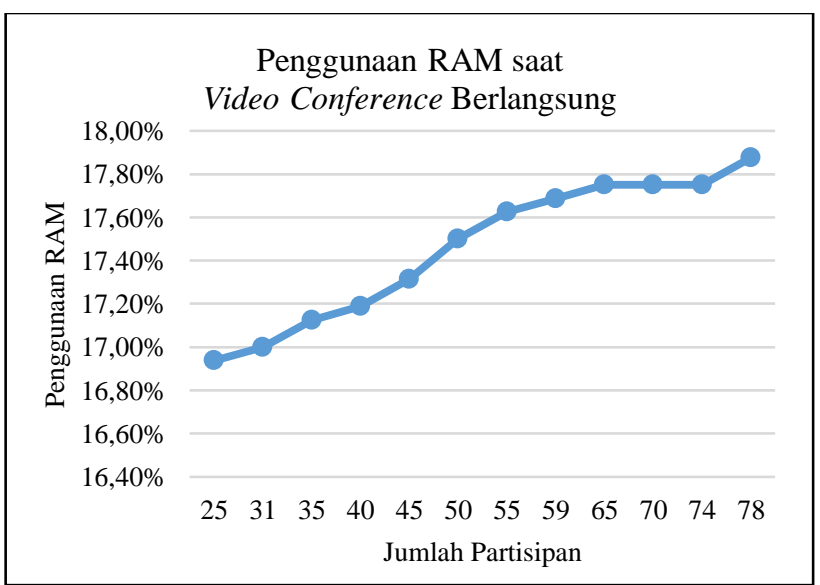

Gambar 6. Persentase penggunaan RAM pada seluruh variasi pengujian

Untuk persentase penggunaan CPU diilustrasikan pada Gambar 6. Penggunaan CPU core-1 secara umum lebih tinggi dibandingkan dengan core lainnya, terutama pada jumlah partisipan 30, 65 dan 74 partisipan. Penggunaan terendah pada core-1 yaitu sebesar $3,7 \%$ pada 25 partisipan dan tertinggi sebesar $38,1 \%$ pada 74 partisipan. Untuk core-2, persentase terendah sebesa2 2,2\% pada 25 partisipan dan tertinggi sebesar $29,8 \%$ pada 74 partisipan. Pada core-3, terendah sebesar $1,4 \%$ pada 25 partisipan dan tertinggi sebesar $30,3 \%$ pada 25 partisipan. Sedangkan, pada core- 4 terendah sebesar $5 \%$ pada 25 partisipan dan tertinggi sebesar 33,8\% pada 74 partisipan. Dengan demikian dapat dilihat bahwa, penggunaan CPU secara keseluruhan terendah dengan jumlah partisipan sebanyak 25 orang, yaitu pada variasi pertama. Sedangkan, penggunaan CPU tertinggi yaitu pada variasi ke-11 dengan jumlah partisipan sebanyak 74 partisipan. Untuk jumlah partisipan 78 orang, penggunaan CPU lebih rendang dibandingkan dengan 74 partisipan. Dari keseluruhan diperoleh bahwa penggunaan CPU terendah yaitu sebesar $1,4 \%$ dan tertinggi sebesar $38,10 \%$. 


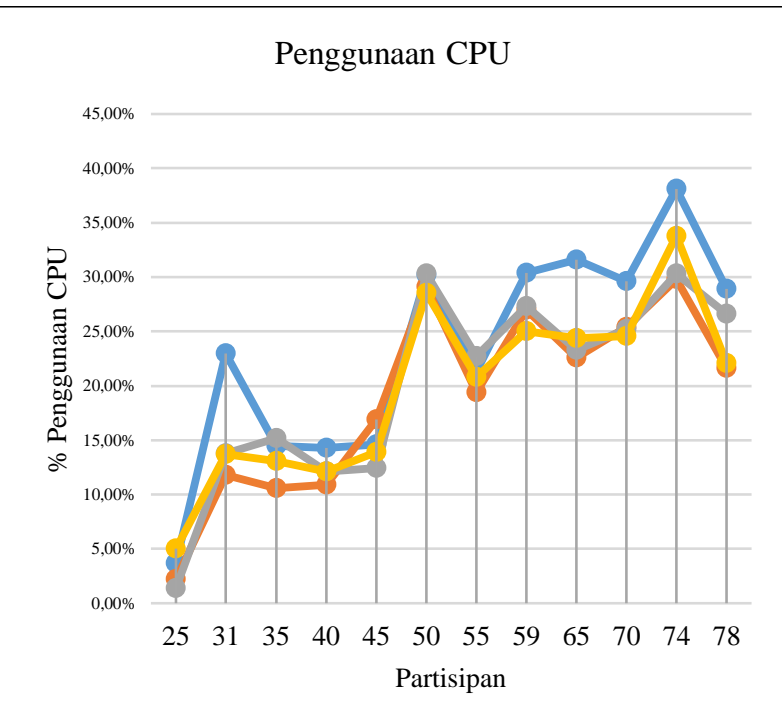

$\longrightarrow$ Core-1 Core-2 Core-3 Core-4

Gambar 7. Persentase penggunaan CPU pada seluruh variasi pengujian.

Berdasarkan pengujian dieproleh bahwa untuk penggunaan RAM dan CPU secara umum meningkat seiring pertambahan jumlah partisipan. Namun, pada jumlah partisipan terbanyak yaitu 78 orang, penggunaan $\mathrm{CPU}$ lebih rendah dibandingkan pada skenario 70 dan 74 partisipan.

\section{KESIMPULAN}

Sistem video conference menggunakan Jitsi dengan memanfaatkan layanan cloud dari Amazon EC2 dapat berjalan dengan baik. Hal ini dinilai dari penggunaan seluruh fitur yang dapat digunakan dengan keberhasilan $100 \%$. Selain itu, untuk kapasitas sumber daya EC2 t2.xlarge, untuk RAM dan CPU dengan jumlah partisipan 25 hingga 78 partisipan menghasilkan rata-rata pemakaian RAM adalah 2,79 GB atau sebesar $17 \%$ dari 16 GB RAM yang tersedia. Sedangkan, pada penggunaan CPU secara umum maksimal pemakaian CPU adalah 38\%. Hal ini menunjukkan kemampuan server masih bisa di optimalkan lagi untuk partisipan diatas 100 partisipan dan bisa digunakan untuk beberapa pertemuan online secara bersamaan.

Pengujian pada artikel ini terbatas pada aspek variasi jumlah partisipan. Pada penelitian selanjutkan sebaiknya juga dilakukan pengujian terhadap variasi kondisi kamera partisipan yang diaktifkan atau tidak. Sehingga, nanti dapat dilihat pengaruhnya terhadap penggunaan sumber daya.

\section{REFERENSI}

[1] D. W. Irawanto, K. R. Novianti, and K. Roz, "Work from Home: Measuring Satisfaction between Work Life Balance and Work Stress during the COVID-19 Pandemic in Indonesia," 2021.

[2] Mendagri, "Instruksi mendagri No. 30 tahun 2021 tentang Pemberlakuan Pembatasan Kegiatan Masyarakat Level 3, Level 2, dan Level 1 Corona Virus
Disease 2019 di Wilayah Jawa dan Bali,” 2021.

[3] A. B. Kusuma, A. Yusuf, and A. Hidayat, "Implementasi Dan Analisis Server Bigbluebutton Dalam Pemanfaatan Meeting Online Pada Masa Pandemic," Walisongo J. Inf. Technol., vol. 2, no. 1, 2020, doi: 10.21580/wjit.2020.2.1.5572.

[4] R. H. Hardyanto and H. D. Surjono, "Pengembangan Dan Implementasi E-Learning Menggunakan Moodle Dan Vicon Untuk Pelajaran Pemrograman Web Di Smk," J. Pendidik. Vokasi, vol. 6, no. 1, p. 43, 2016, doi: 10.21831/jpv.v6i1.6675.

F. B. Insights, "Video Conferencing Market Size,” 2021.

[6] D. Laksmiati, "Implementasi Cloud Based Video conference System Menggunakan Jitsi,” J. Akrab Juara, vol. 4, no. 1, pp. 219-225, 2019, [Online]. Available: http://akrabjuara.com/index.php/akrabjuara/article/view 1522 .

[7] M. Jamil, A. Khairan, and A. Fuad, "Implementasi Aplikasi Telemedicine Berbasis Jejaring Sosial dengan Pemanfaatan Teknologi Cloud Computing," J. Edukasi dan Penelit. Inform., vol. 1, no. 1, 2015, doi: 10.26418/jp.v1i1.9930.

[8] M. S. Rumetna, "Pemamfaatan Cloud Computing Pada Dunia Bisnis," J. Teknol. Inf. dan Ilmu Komput., vol. 5, no. 3, p. 305, 2018.

[9] M. A. Muslim and N. A. Retno, "Implementasi Cloud Computing Menggunakan Metode Pengembangan Sistem Agile," Sci. J. Informatics, vol. 1, no. 1, 2015, doi: 10.15294/sji.v1i1.3639.

[10] S. Mirghani and H. Hajjdiab, "Comparison between amazon S3 and google cloud drive," ACM Int. Conf. Proceeding Ser., pp. 250-255, 2017, doi: $10.1145 / 3158233.3159381$.

[11] M. Talha, M. Sohail, and H. Hajji, "Analysis of research on amazon AWS cloud computing seller data security," Int. J. Res. Eng. Innov., vol. 04, no. 03, pp. 131-136, 2020, doi: $10.36037 /$ ijrei.2020.4302.

[12] J. Varia and S. Mathew, "Overview of Amazon Web Services (Survey Report)," no. January, pp. 1-30, 2014, [Online]. Available: http://media.amazonwebservices.com/AWS_Overview. pdf.

[13] A. Sleit, N. Misk, F. Badwan, and T. Khalil, "Cloud Computing Challenges with Emphasis on Amazon EC2 and Windows Azure," Int. J. Comput. Networks Commun., vol. 5, no. 5, pp. 35-44, 2013, doi: 10.5121/ijenc.2013.5503.

[14] AWS, “Amazon EC2 Instance Types,” 2021. https://aws.amazon.com/ec2/instance-types/?nc1=h_ls.

[15] B. Bektaş and E. Dandil, "Development of Android Based Mobile Video conference Application Using Jitsi Meet Platform Jitsi Meet Platformu Kullanılarak Android Tabanlı Mobil Video Konferans Uygulamasının Geliştirilmesi,” pp. 427-433, 2021. 
[16] D. Kovacevic, "Some Aspects of Online Teaching of Technical English," 2021 20th Int. Symp. INFOTEHJAHORINA, INFOTEH 2021 - Proc., no. March, pp. 17 19, 2021, doi: 10.1109/INFOTEH51037.2021.9400687. 